\title{
The Historical Journal
}

http://journals.cambridge.org/HIS

Additional services for The Historical Journal:

Email alerts: $\underline{\text { Click here }}$

Subscriptions: Click here

Commercial reprints: $\underline{\text { Click here }}$

Terms of use : $\underline{\text { Click here }}$

\section{BRITISH REPRESENTATIVES AND THE} SURVEILLANCE OF ITALIAN AFFAIRS, 1860-70*

\author{
O. J. WRIGHT
}

The Historical Journal / Volume 51 / Issue 03 / September 2008, pp 669 - 687

DOI: 10.1017/S0018246X08006961, Published online: 04 September 2008

Link to this article: http://journals.cambridge.org/abstract_S0018246X08006961

How to cite this article:

O. J. WRIGHT (2008). BRITISH REPRESENTATIVES AND THE SURVEILLANCE OF ITALIAN AFFAIRS, 1860-70*. The Historical Journal, 51, pp 669-687 doi:10.1017/S0018246X08006961

Request Permissions : $\underline{\text { Click here }}$ 


\title{
BRITISH REPRESENTATIVES AND THE SURVEILLANGE OF ITALIAN AFFAIR S, 1860-70*
}

\author{
O. J. WR I G H T
}

Kingston University

\begin{abstract}
During the nineteenth century the British consular service was often dismissed as an organization with purely commercial responsibilities. A succession of governments and diplomats insisted upon this notion, despite the fact that at certain times both relied very much on consular officials for information on foreign affairs. This dependence was especially evident in Italy during the decade after I860, when British leaders had lent their moral and diplomatic support to the creation of the modern Italian state against considerable international opposition. During this period their desire not to see the achievement undone led them to maintain a close watch on Italian affairs. The contribution made in this area by the consular service, and the manner in which it was reorganized in response to Italian unification, show how such a role could take priority over its other functions. Although this state of affairs was no doubt exceptional on account of the remarkable level of British interest in the Unification of Italy, it nonetheless provides a clear demonstration of how the organization could be used under certain circumstances. The extent to which British consuls were used to monitor affairs in post-unification Italy also encourages reflection upon the widespread view that British foreign policy rejected interventionism in favour of isolation from European affairs during the I86os.
\end{abstract}

The Unification of Italy (I859-6I) suited the ideology and interests of Victorian Britain. When British leaders lent their moral and diplomatic support to the creation of the modern Italian state in I86o, their policy reflected the general aim of exporting Britain's constitutional model either by influence or intervention. ${ }^{1}$ It was also consistent with a considerable British artistic and literary affection

Faculty of Arts and Social Sciences, Kingston University, Penrhyn Road, Kingston upon Thames. Surrey, KTI $2 E E$ o.wright@kingston.ac.uk

* For various questions and comments which have been of use in the preparation of this article, I wish to thank the following: Martin Blinkhorn and Steve Constantine (both Lancaster University), Richard Bosworth (University of Western Australia), members of the Italian History Seminar (Institute of Historical Research), and the Historical foumal's anonymous reviewer. I am also grateful to Lord Clarendon for permission to quote from the Clarendon papers.

1 See Derek Beales, England and Italy, I859-1860 (London, I96I), and Russell to Hudson, 27 Oct. I860, in Selections from speeches of Earl Russell I8I7 to I84I and from despatches I859 to I865, II (London, I870), pp. $328-32$. 
for Italy, ${ }^{2}$ and a great popular enthusiasm for Garibaldi and the Italian nationalist cause. ${ }^{3}$ The creation of a single Italian kingdom posed no threat to British interests and offered potential advantages to Britain as a Mediterranean power. Most research on the British involvement in the Risorgimento has hitherto focused on the critical phase of Italian unification prior to I86r. ${ }^{4}$ By contrast, little attention has been paid to the British interest in Italy during the following decade, when Italian affairs were eclipsed by the American Civil War (I86I-5) and the Unification of Germany (by I871). ${ }^{5}$ Nonetheless, throughout the I86os the British watched developments in Italy closely, especially while it was the policy of Lords Palmerston and Russell 'to see the independence of Italy maintained, and the peace of Europe preserved '. ${ }^{6}$ In seeking to realize these objectives the Foreign Office relied primarily on the combined efforts of the diplomatic and consular services for information on Italian affairs. ${ }^{7}$

Throughout the nineteenth century these two organizations performed ostensibly different functions, resulting in misconceptions concerning their respective roles. For decades British governments, Foreign Office staff, and diplomatic representatives perpetuated the notion that the work of each service was entirely different from that of the other. As a result diplomats tend to be regarded as implementers of foreign policy, while consuls are normally considered to have existed for the promotion of trading interests and to attend to the needs of Britons overseas. ${ }^{8}$ However, it should be noted that during the eighteenth and nineteenth centuries the everyday value of diplomats lay in the reporting of overseas events rather than in negotiations, ${ }^{9}$ and that at times of particular upheaval they would commentate not only on political affairs but also

2 See C. P. Brand, Italy and the English Romantics: the Italianate fashion in early nineteenth-century England (Cambridge, I957); John Pemble, The Mediterranean passion: Victorians and Edwardians in the south (Oxford, 1987); Maura O'Connor, The romance of Italy and the English imagination (Basingstoke, I998); Roderick Cavaliero, Italia romantica: English Romantics and Italian freedom (London, 2005); A. N. Wilson, The Victorians (London, 2002), pp. 84-92.

${ }^{3}$ See Derek Beales, 'Garibaldi in England: the politics of Italian enthusiasm', in John A. Davis and Paul Ginsborg, eds., Society and politics in the age of the Risorgimento (Cambridge, I99I), pp. I842 I6.

${ }^{4}$ For example, see Beales, England and Italy; Mario Tedeschi, Francia e Inghilterra di fronte alla Questione Romana, I859-I86o (Milan, I978); Nicholas E. Carter, 'Sir James Hudson, British diplomacy and the Italian question: February I858 to June I86I' (Ph.D. thesis, University of Wales Cardiff, I993); Nick Carter, 'Hudson, Malmesbury and Cavour: British diplomacy and the Italian question, February I858 to June i859', Historical foumal, 4o (1997), pp. 389-413.

${ }^{5}$ For rare examples of such work, see H. E. Priestley, 'British policy in the Italian question, I866-I87I' (Ph.D. thesis, London, I93I); Massimo de Leonardis, L'Inghilterra e la questione Romana I859-7o (Milan, I980).

6 Russell to Hudson, I4 Mar. I862, The National Archives (hereafter TNA), FO I70/99.

7 See also Owain James Wright, 'The information service: British diplomats and consuls in Italy, I86I-I870' (Ph.D. thesis, Lancaster, 2005).

${ }^{8}$ For the official responsibilities of consular officials, see E. W. A. Tuson, The British consul's manual: being a practical guide for consuls as well as for the merchant shipowner, and master mariner (London, I856).

${ }^{9}$ Jeremy Black, British diplomats and diplomacy, I688-I80o (Exeter, 200I), p. $5^{8 .}$ 
on social and economic conditions. ${ }^{\mathbf{1 0}}$ The history of the British consular service has been relatively neglected by historians, and the contribution it made to the information-gathering process has been largely overlooked. ${ }^{\mathbf{1 1}}$ Whereas French consuls have been recognized as being the 'eyes and ears' of their Foreign Office, ${ }^{12}$ their British counterparts have been dismissed with the assertion that even though they might 'occasionally have acted as sources of political intelligence, they were under no obligation to do so' ${ }^{13}$ It is the aim of this article to improve our understanding of the level of co-operation between the diplomatic and consular services when describing and explaining foreign affairs.

Refreshing approaches have contributed to the resurgence of the study of British overseas representatives, ${ }^{14}$ and this work follows a number of others which have focused on such personalities and their interaction with their host environments. ${ }^{15}$ During the nineteenth century dramatic improvements in communications technology removed the traditional autonomy of diplomats but left their importance as gatherers of information intact, if not increased. ${ }^{\mathbf{1 6}}$ Their despatches served simultaneously as means for the communication of new information as well as for the storage of old, ${ }^{\mathbf{1 7}}$ and in preparing them British diplomats in Italy relied enormously upon a harmonious and effective working relationship with their consular colleagues. When the service was reorganized in response to Italian unification, its ability to provide intelligence on Italian affairs was prioritized over its commercial functions. This situation was no doubt exceptional owing to the level of British interest in Italian unification. Nonetheless, it demonstrates how

${ }^{10}$ Michael Hughes, 'British diplomats in Russia on the eve of revolution', European History Quarterly, 24 (I994), pp. 342-3.

11 The only general history of the British consular service is D. C. M. Platt, The Cinderella service: British consuls since I825 (London, I97I). Other works include Lucia Patrizio-Gunning, 'The British consular service in the Aegean, I820-I860' (Ph.D. thesis, London, I997); G. W. Rice, 'British consuls and diplomats in the mid-eighteenth century: an Italian example', English Historical Review, 92 (I977), pp. 843-46; D. C. M. Platt, 'The role of the consular service in overseas trade, I825-I9I4', Economic History Review, n.s., I5 (I963), pp. 494-512; Peter Byrd, 'Regional and functional specialisation in the British consular service', fournal of Contemporary History, 7 (1972), pp. I27-45; John McDermott, 'The Foreign Office and its German consuls before I9I4', fournal of Modern History, 50, On Demand Supplement (I978), pp. IO0I-34; P. D. Coates, The China consuls: British consular officers, I843-1943 (Hong Kong, I988). $\quad 12$ Patrizio-Gunning, The British consular service in the Aegean, pp. I2-I3.

13 Platt, The Cinderella service, p. 6.

14 David Reynolds, 'International history, the cultural turn and the diplomatic twitch', Cultural and Social History, 3 (2006), pp. 75-91. See also Patrick Finney, 'The diplomatic temptation', Antony Best, "'The cultural turn" and the international history of East Asia', and David Reynolds, 'Culture, diplomacy and language', Cultural and Social History, 3 (2006), pp. 472-95.

${ }^{15}$ For example, see Gordon Daniels, Sir Harry Parkes: British representative in Japan, I865-I883 (Richmond, I996); Karina Urbach, Bismarck's favourite Englishman: the embassy of Odo Russell to Berlin (London, I999); Scott W. Murray, Liberal diplomacy and German Unification: the early career of Robert Morier (Westport, CT, and London, 2000); Katie Hickman, Daughters of Britannia: the lives and times of diplomatic wives (London, 2000).

${ }^{16}$ John Ure, Diplomatic bag: an anthology of diplomatic incidents and anecdotes from the Renaissance to the Gulf War (London, I994), p. 5 .

17 Like newspapers; see Daniel R. Headrick, When information came of age: technologies of knowledge in the age of reason and revolution, I700-I850 (New York, 2000), p. 5 . 
effectively the consular service could be used under certain circumstances. It also encourages reflection upon the view that British foreign policy abandoned interventionism in favour of isolation from European affairs during the I86os.

After the proclamation of the kingdom of Italy in I86I the British prime minister and foreign secretary, respectively Lords Palmerston and Russell, hoped that the new state's emergence would resolve the Italian question which had threatened the peace of Europe for decades. They were also anxious to see that the country's unification would not be undone, either by its enemies or through the folly of the Italians themselves. Italy had few international friends, and its early leaders failed to gain any by declaring their intention to complete Italian unification by acquiring the still-independent papal state of Rome and Austrian-ruled Venetia. ${ }^{18}$ Besides external dangers, Italy also faced massive internal difficulties. Although legitimized by a number of plebiscites and celebrated in Britain as the realization of a national dream, ${ }^{19}$ many Italians actually regarded unification as little more than a Piedmontese conquest, ${ }^{20}$ and in southern Italy and Sicily widespread opposition precipitated a virtual civil war. During the summer of I86o Garibaldi's arrival in Naples had prompted the British envoy Sir Henry Elliot to predict that 'it is by no means impossible that we must be worse before we are better ${ }^{21}{ }^{21}$ By the winter Odo Russell, Elliot's colleague in Rome, had noted that an unlikely alliance of republican radicals and papal reactionaries was conspiring to oppose Italian unification. ${ }^{22}$ Aware of the internal and external fragility of the new state, the foreign secretary stressed the importance of his representatives relaying

full accounts of the temper, condition and prospects, of the various Provinces of which the proposed new Kingdom is composed ... every step taken at Naples [in the unruly south], and confirmed or overruled at Turin [Italy's first capital], is not merely a matter of great interest in itself, but has an important bearing on the future welfare of Italy, and the future Peace of Europe. ${ }^{23}$

Hence the Foreign Office sought to use the consular service for the acquisition of intelligence on conditions and developments in Italy.

To this end, and with a view to alleviating any confusion generated by the country's unification, a memorandum was despatched to all the British consular representatives in Italy. It contained a rare acknowledgement of the political side of their role:

it is the duty of Her Majesty's Consuls to keep HM's Representative under whose control they are placed, fully informed on all matters, political as well as commercial, which may

\footnotetext{
18 Denis Mack Smith, Cavour (London, I985), pp. 232-3, 26o-3.

19 A. J. P. Taylor, The struggle for mastery in Europe (Oxford, I97I), p. I24.

20 Nicholas Doumanis, Inventing the nation: Italy (London, 200I), pp. 86-7.

21 Elliot to Minto, 2 July I86o, Minto papers, National Library of Scotland, MS I2250.

22 Odo Russell to Lord Russell, 30 Dec. I86o, in Noel Blakiston, ed., The Roman question: extracts from the despatches of Odo Russell from Rome, $1858-1870$ (London, I962), p. I46.

${ }^{23}$ Russell to Hudson, I5 Mar. I86i, TTNA, FO I67/I22.
} 
come under their observation, and they should accordingly furnish him, simultaneously with the despatch of the originals, with copies of all despatches, except merely formal Returns, which they may address to this Office. ${ }^{24}$

In fulfilling these instructions the consular service proved enormously valuable to the diplomats who served as British envoys to Italy during the I86os. The first, Sir James Hudson (I86I-3), had already served in Piedmont since I852; as the Unification of Italy brought about the aggrandizement of that kingdom, so too did it increase the scale of his responsibilities. Before I86I Hudson had been charged with reporting on the affairs of Piedmont and its island possession of Sardinia; thereafter he found himself expected to provide information on events throughout the whole of Italy. Hudson and his successors, Sir Henry Elliot (I863-7) and Sir Augustus Paget (I867-83), had to do this while resident in the cities which served in turn as the seat of the Italian government - Turin $\left(\mathrm{I}^{86} \mathrm{I}-5\right)$ and Florence (I865-7I) - before Rome became the capital of Italy in I87I. They were seldom able to travel away from the British diplomatic legation in order to see other parts of the country for themselves, and even when able to do so events could conspire against them. While accompanying King Vittorio Emanuele on a visit to southern Italy in I862 Hudson found his journey a valuable opportunity to see how Tuscany was adapting to Italian unification, but was unable to take similar advantage of his time in Naples after being struck by illness. ${ }^{25}$ Paget hoped to gauge the state of public opinion in Turin on the occasion of a royal wedding in I868, but found his efforts frustrated by his ceremonial duties. ${ }^{26}$ In i869 Paget enjoyed a rail journey through Emilia-Romagna and Lombardy in the company of the prince and princess of Wales, but found little opportunity to take much account of the places through which he passed. ${ }^{27}$ During the I86os no British diplomat was able to venture much further south than Naples, or over the sea to Sardinia or Sicily. The fact that they were usually confined to their cities of residence has led to their being accused of simply cribbing their reports 'straight from the morning's newspapers '. ${ }^{28}$ Hudson, Elliot and Paget certainly took advantage of the press, but they also relied on other sources, including foreign politicians, domestic officials, travellers, and other acquaintances. However, in terms of accessibility and reliability none could rival the permanent hierarchy of British consuls based in Italy, employed by the Foreign Office, and owing their allegiance to the crown.

During the eighteenth century British governments had attempted to extend the consular service in Italy's predecessor states. ${ }^{29}$ At the beginning of the nineteenth century British merchants had called for its expansion in order to exploit

${ }^{24}$ See enclosure in Hammond (for Russell) to Hudson, 2 May I86r, TNA, FO 45/r.

${ }^{25}$ Hudson to Russell, 27 May 1862, Russell papers (hereafter RP), TNA, PRO 30/22/69.

${ }^{26}$ Paget to Stanley, 25 Apr. I868, TTNA, FO 45/125.

27 Paget to Clarendon, 6 May i869, TTNA, FO 45/I4I.

${ }^{28}$ Martin Clark, Modern Italy, I87I-I995 (2nd edn, London, I996), p. 7.

${ }^{29}$ Rice, 'British consuls and diplomats', pp. $834^{-4} 6$. 
Italy's developing markets. ${ }^{30}$ By I86r the service was more extensive in Italy than in any other part of the world, with the exception of the Ottoman empire. Significant consular offices existed at Milan, Genoa, Massa Carrara, Livorno, Naples, Palermo, and Cagliari. There were also posts at Venice, which was ceded to Italy in I866, and at Rome and Civitavecchia, which were occupied by the Italians in 1870. Within a few years the offices at Milan and Massa Carrara were closed, while significant new posts were created at Turin and Brindisi. In addition to these, there existed many small vice-consulates throughout the country. The conventional post and the novelty of the telegraph ensured that British diplomats had good communications links with the occupants of these offices, who could be requested to provide them with information on any matter within their consular district. By being of British birth, or Italians who had sworn an oath of allegiance, consuls could reasonably be relied upon to provide intelligence regardless of its strategic importance or its potential to embarrass their host government.

For example, in both 1862 and I867 Garibaldi and his volunteers attempted to conquer Rome for Italy, acting to some degree in collusion with the king and his premier, Rattazzi. ${ }^{31}$ On both occasions the British government gained advance warning of these potentially explosive events courtesy of the zealous British consul at Genoa, Montagu Brown. During the I85os Genoa had developed a reputation as a centre for the democratic movement in Italy ${ }^{32}$ and when a meeting of Italian nationalists and revolutionaries took place in the city in 1862 Brown exceeded his commercial brief by some margin. Apparently finding details easy to come by, he provided Hudson with frequent accounts of the proceedings, warned of the revolutionary committee's intention to extend 'throughout the whole of Italy its sphere of action', and suggested that it posed a considerable threat to the tranquillity of the new state. ${ }^{33}$ Brown claimed to have used every means in his power to obtain accurate information, and his apprehension was transferred to the Foreign Office when Hudson highlighted the potential danger of these events in a city bursting 'with the restless spirits of all Italy'. ${ }^{34}$ Once Garibaldi and his volunteers had sailed for Sicily, abandoning their original intention of attacking Austria in favour of marching on Rome, British attention was transferred accordingly. Throughout the crisis the British consuls in the island followed the volunteers' movements closely. From Livorno in Tuscany and Ancona in Marche Consul Alexander Macbean and Vice-Consul Gustavus Gaggiotti reported respectively that large numbers of young men were converging on those ports in

${ }^{30}$ John Jackson, Reflections on the commerce of the Mediterranean: deduced from actual experience during a residence on both shores of the Mediterranean Sea (London, I804), p. I Io.

31 Denis Mack Smith, Italy and its monarchy (New Haven, CT, and London, I989), p. I3.

32 Clara M. Lovett, The democratic movement in Italy, I830-I876 (Cambridge, MA, and London, I982), p. 175 .

${ }^{33}$ Brown to Hudson, io Mar. I862, copy in Hudson to Russell, i I Mar. I862, Brown to Hudson, i Mar. I862, extract in Hudson to Russell, I2 Mar. I862, and Brown to Hudson, I2 Mar. I862, copy in Hudson to Russell, I4 Mar. I862, all TNA, FO 45/22.

${ }^{34}$ Hudson to Russell, I4 Mar. I862, TNA, FO 45/22. 
the hope of sailing to join Garibaldi. ${ }^{35}$ The British consul at Palermo, John Goodwin, followed the development of the volunteer force and gave frequent accounts of its progress through the island. Goodwin also commented upon the local authorities' efforts to prevent the publication of Garibaldian propaganda and to impede the campaign ${ }^{36}$ and was ably assisted by the British vice-consuls in the island.$^{37}$ Eventually Garibaldi sailed to Aspromonte in Calabria unchecked by the navy, but his force was defeated by a division of bersaglieri sent by an Italian government which had lost its nerve and bowed to international pressure. ${ }^{38}$ The fact that the British government was kept so well informed of these events was largely the achievement of its consuls. It was understandably able to obtain little information from Rattazzi's administration, and although the most important incidents were covered in Britain by The Times - such as a speech in which Garibaldi condemned the French emperor and the pope, and called for the forceful liberation of Rome and Venetia - this was usually only several days after the event. ${ }^{39}$ By contrast, British consuls would relate affairs in detail as a matter of routine,${ }^{40}$ and particularly urgent matters would be reported by telegraph so that the news would be received within hours.

There is an interesting contrast between the efficiency with which the consular service provided accurate and detailed information for the British legation to Italy during Garibaldi's campaign of 1862 and his final attempt to complete the Unification of Italy in 1867 . While Garibaldi was again preparing his volunteer force in Genoa the British legation was once more well informed by Consul Brown. But on this occasion Garibaldi's plan of marching on Rome from the north ensured that the action took place in a vast swathe of territory where there were few British consular offices. Consequently once the campaign was underway Paget found it difficult to follow events from his post in Florence, despite actually being much closer to the scene of events near Rome than Hudson had been during the earlier campaign in Sicily. The only British consuls stationed in the region were those in Civitavecchia and Rome itself, and although they did communicate with the British legation their relationship with Paget was enigmatic owing to their location in the independent papal state. The fact that they were not obliged to communicate with him as a matter of routine caused some confusion, ${ }^{41}$ and officially Paget was left to rely on whatever information the Italian government - once again under Rattazzi - would share with him. ${ }^{42}$ And

${ }^{35}$ Macbean to Hudson, 20 July I862 and 2 Aug. I862, copies in Hudson to Russell, 2 Aug. I862, TNA, FO 45/25; Gaggiotti to Hudson, 4 Aug. I862, copy in Hudson to Russell, 8 Aug. I862, TNA, FO 45/25. $\quad{ }^{36}$ Hudson to Russell, 7 Aug. I862, TNA, FO 45/25.

${ }^{37}$ Rickards to Hudson, 4 Aug. I862, copy in Hudson to Russell, 8 Aug. I862, TNA, FO 45/25.

${ }^{38}$ George Martin, The red shirt and the cross of savoy: the story of Italy's Risorgimento, $174^{8-18}{ }^{87 I}$ (London, I969), p. 664 .

39 Times, 17 July 1862.

${ }_{40}$ Goodwin to Hudson, 6 July I862, copy in Hudson to Russell, I2 July I862, TNA, FO 45/24.

${ }^{41}$ Paget to Stanley, by telegraph, 25 Oct. I867, TNA, FO 45/ Io8.

${ }^{42}$ Paget to Stanley, I3 Oct. I867, TNA, FO 45/107. 
on this occasion he did have to resort to cribbing reports from the Italian newspapers. ${ }^{43}$

The provision of information by members of the consular service might not have determined the underlying principles of British foreign policy, but it could certainly prompt government action. Without the efforts of the British consuls in Italy, such a quick and detailed understanding of the situation is not likely to have been formed in London. In response to the news of the meeting at Genoa prior to the Garibaldian expedition of 1862, Lord Russell ordered Hudson to insist that Rattazzi 'keep his eye upon these men' and ensure that they were not permitted 'to invade other Countries'. ${ }^{44}$ Although Russell lamented that a promise from Rattazzi's government 'would not be worth a pinch of snuff', ${ }^{45}$ his efforts succeeded in securing an Italian undertaking that everything would be done to prevent the volunteers' embarkation. ${ }^{46}$ Such clandestine activities had played a vital part in the Unification of Italy, and had been exploited by the government of Count Cavour. ${ }^{47}$ Palmerston and Russell were well aware of this fact, and had sought to achieve peaceful settlements to both the Roman and Venetian questions in ${ }^{186}{ }_{1}{ }^{48}$ In 1862 the news from Italy spurred them into renewing their efforts by approaching the French and Austrian governments on the subject, emphasizing the danger posed by the nationalists, and stressing the mutual advantages of finding an amicable solution to each problem. ${ }^{49}$ Their failure to see these questions resolved resulted in Italy suffering the humiliation of having to halt its national hero at Aspromonte in 1862, and drove the Italians into alliance with Prussia and war against Austria in I866. During the build-up to this conflict, the pattern of British action in the Garibaldian campaign was repeated. The new foreign secretary, Lord Clarendon, was furnished with a sound understanding of the greatly excited state of Italian public opinion by British representatives in Italy which persuaded him to lecture the Italian government on the likely perils of its sabre-rattling. ${ }^{50}$ His knowledge of Italy's domestic problems led him to suggest that before threatening the international peace in pursuit of such aims, the Italians would do well to concentrate on setting their own 'house in order' ${ }^{51}$ His awareness of the futility of such efforts in Italy, owing to the determination of the Italian government to strike a blow against Austria in deference to public

\footnotetext{
43 See Paget to Stanley, I6, I8, I9, and 20 Oct. I867, TNA, FO 45/ı7.

44 Russell to Hudson, i7 Mar. I862, TNA, FO I70/99; Russell to Hudson, 7 May i862, TNA, FO I70/IO0.

${ }_{45}$ Russell to Bloomfield, 5 Mar. I86I, in Noel Blakiston, ed., Il problema veneto e l'Europa, I859-I866, II: Inghilterra (Venice, I966), p. 560. $\quad{ }^{46}$ Hudson to Russell, 25 Mar. I862, TNA, FO 45/22.

47 Derek Beales and Eugenio F. Biagini, The Risorgimento and the Unification of Italy (2nd edn, Harlow, 2002), p. I27.

48 Ivan Scott, The Roman question and the powers, I848-I865 (The Hague, I969), pp. 223-52; Frank J. Coppa, The origins of the Italian wars of independence (London and New York, NY, I992), p. II5.

49 Russell to Cowley, i7 Mar. and i9 Mar. I862, Fane to Russell, I4 May i862, and Bloomfield to Russell, I5 May I862, in Blakiston, ed., Il problema veneto, pp. 566, 568, 578-80.

50 Elliot to Clarendon, 3 May i866, TNA, FO 45/86.

51 Clarendon to Elliot, 23 Apr. I866, Bodleian Library, Clarendon papers, MS Clar. dep. c. I43.
} 
opinion in the country, led him into trying to deprive the Italians of their motive by pursuing the peaceful cession of Venetia in Vienna. ${ }^{52}$ It is unlikely that such British action would have been attempted, or at least not in the manner in which it was pursued, had the Foreign Office not been so well informed of the state of affairs in Italy.

The level of efficiency with which the consular hierarchy could meet the demands of British diplomats is clear in the action taken by Elliot following the announcement of the September Convention in I864. This agreement was intended as a temporary solution to the Roman question, by which the French promised to end their military protection of the pope on the condition that the Italians settle upon Florence as an alternative capital. The residents of Turin reacted violently to the announcement, their demonstrations resulting in a tragic massacre when nervous carabinieri opened fire on the crowd. Amidst the disturbances Elliot sent a circular telegram to each of the main consulates in Italy, enquiring as to how the news had been received. The responses were prompt and provided a clear impression of the state of public opinion throughout the country, revealing the unpopularity of the Piedmontese domination of Italy ${ }^{53}$ From Naples Consul-General Bonham reported that some people believed their city should have been considered as a potential capital, although they approved of Florence as a more central location, and hoped that its elevation might alleviate their animosity towards the Piedmontese. ${ }^{54}$ In Tuscany Consul Macbean observed that many people considered the news 'too good to be true', not because of the promotion of Florence, but rather on account of their disapproval of how Italy had been 'Piedmontized' rather than Italianized. ${ }^{55}$ From Vice-Consul Gaggiotti in Ancona Elliot learnt that the people of the Marche region entirely disapproved of the rioting in Turin and were 'anything but pleased' with the Piedmontese predominance. ${ }^{56}$ From Genoa, the volatile centre of Italian revolutionary activities and a city which had not welcomed its own absorption by Piedmont in $1815,{ }^{57}$ Consul Brown explained how the news excited interest without giving rise to any public disorder. The choice of Florence as a temporary capital was regarded with 'great indifference', although the Turinese were considered to have shown 'a paltry and selfish spirit' in their demonstrations ${ }^{58}$ In Sardinia, which had been ruled by the Piedmontese since 1720, Consul William Craig observed that the people of Cagliari approved 'cordially' of the September Convention; the privileged viewed it as 'an important advance' towards Italy's

${ }^{52}$ Bloomfield to Clarendon, I2 Apr. I866, Russell to Apponyi, I6 Apr. I866 and 3 May I866, in Blakiston, ed., Il problema veneto, pp. 80o, 805-6, 850.

53 Elliot to Russell, 4 Oct. I864, TNA, FO 45/59.

54 Bonham to Elliot, 26 Sept. I864, copy in Elliot to Russell, 4 Oct. I864, TNA, FO 45/59.

55 Macbean to Elliot, 27 Sept. I864, copy in Elliot to Russell, 4 Oct. I864, TNA, FO 45/59.

56 Gaggiotti to Elliot, 26 Sept. I864, copy in Elliot to Russell, 4 Oct. I864, TNA, FO 45/59.

57 Harry Hearder, Italy in the Age of Risorgimento, I79o-I870 (London and New York, NY, I983), pp. $53-4$.

58 Brown to Elliot, 26 Sept. I864, copy in Elliot to Russell, 4 Oct. I864, TNA, FO 45/59. 
ambition of acquiring Rome, while the poor rejoiced 'at the prospect of being emancipated' from Turin. Craig observed that 'the Sardes [sic] never reciprocated any very friendly feeling' with the Piedmontese, and believed that the Italian government needed to reverse Turin's appearance of having conquered Italy by showing 'Italy as having conquered Turin' ${ }^{59}$ From unruly Sicily Goodwin reported that there was 'ill-blood' between the Turinese and the Palermitans, and that the news raised hopes of a change in government policy towards the island ${ }^{60}$ Interestingly Joseph Rickards, the vice-consul at Messina, pre-empted Elliot's request for information by writing of a 'joyful demonstration' in the public gardens and of a band marching through the streets playing patriotic anthems. ${ }^{61}$ Upon receiving Elliot's instructions he elaborated upon this, promising to keep the British legation 'accurately and regularly informed of the state of public feeling' in his consular district. ${ }^{62}$

While some consuls reported the public reaction to the news in greater detail than others, all did so without questioning or neglecting their responsibility to do so. Indeed, consuls in southern Italy, Sardinia, and Sicily had already proved particularly effective in providing the British legation and government with information on events in the most remote parts of Italy. Soon after their endorsement of the Unification of Italy in I86o British leaders had looked to Sardinia in the hope of anticipating how southern Italy and Sicily might adapt to rule from the north. Russell ordered a report on how the island had adapted to constitutional government since its voluntary but controversial administrative and legal fusion with Piedmont in $1847{ }^{63}$ In response Consul Craig produced a very extensive paper on the social and economic conditions of the island, observing that the government had 'not been backward' in attempting to ameliorate its 'moral and social condition'. ${ }^{64}$ Around the same time Goodwin had also been asked to provide an account of the efforts made by the Italian government in Sicily after unification, including details of public works schemes being undertaken in order to rebuild Palermo after Garibaldi's expedition and in order to reconcile the Sicilians to Italian rule ${ }^{65}$ Both officials were assets to the Foreign Office owing to their possession of enormous personal experience of each island. Craig had lived in Sardinia since I818, when the island had possessed 'not a single carriage road', and had been the consul at Cagliari since i846; Goodwin had been appointed to Palermo in I834. Such longevity was commonplace in the

\footnotetext{
${ }^{59}$ Craig to Elliot, 3 Oct. I864, copy in Elliot to Russell, 4 Oct. I864, TNA, FO 45/59.

60 Goodwin to Elliot, 27 Sept. I864, copy in Elliot to Russell, 4 Oct. I864, TNA, FO 45/59.

61 Rickards to Elliot, 24 Sept. I864, extract in Elliot to Russell, 4 Oct. I864, TNA, FO 45/59.

62 Rickards to Elliot, 26 Sept. I864, copy in Elliot to Russell, 4 Oct. I864, TNA, FO 45/59.

63 See Giancarlo Sorgia, ed., La Sardegna nel I848: la polemica sulla 'fusione' (Cagliari, I968); Francesco Floris, Storia della Sardegna (3rd edn, Rome, 2004), pp. 483-6.

64 William Craig, 'The island of Sardinia absolute and constitutional briefly compared', 22 Oct. I86I, in Hudson to Russell, 2 Nov. I86I, TNA, FO 45/9. Craig recorded Russell's original request as dated from 29 Apr. I86I.

65 Goodwin to Hudson, 3 Oct. I86r, copy in Hudson to Russell, ir Oct. I86r, TNA, FO 45/9.
} 
consular service but unmatched in the diplomatic, where appointees seldom remained in the same post for a decade or more. Such lengthy periods of tenure not only eminently qualified many consuls for providing information on local affairs, but also enabled them to set events in context. Even where they had not been resident for very long, professional consuls could still prove adept at collating information on political, social, and economic matters; in I869 Consul Colnaghi, a relatively recent appointment at Turin, provided detailed information on land tenure and economic conditions in Piedmont. ${ }^{\mathbf{6 6}}$

In addition to this ability to provide and explain information on a wide range of matters, such consuls could be expected to afford the British legation and government an interpretation of events which could not necessarily be expected from the Italian authorities. As early as I86I Goodwin had reported from Palermo that a Bourbon counterrevolution was being attempted in the island, making the perceptive prediction that it would fail not through the Sicilians' loyalty to their new Italian rulers but rather because of their preference for independence from the mainland.$^{67}$ On the occasion of a royal visit in 1864 , the Italian government declared itself satisfied with the reception of Prince Umberto by the Sicilians, although British consuls in both Palermo and Messina recorded that it was in fact 'very cold' ${ }^{68}$ Similarly, when the king visited Naples in I869 Consul-General Bonham reported that the Neapolitans were not enthusiastic in their welcome. ${ }^{69}$ Most strikingly, when a major revolt occurred at Palermo in I866 the Italian government attempted to maintain that it was not politically motivated, but the British knew otherwise. The perpetrators were an unlikely alliance of radical insurgents, clerical reactionaries, and people the authorities defined as 'brigands' - impoverished peasants, escaped prisoners, army deserters, former Bourbon employees, and Sicilian autonomists. They overthrew the local administration and established a provisional government before Italian forces arrived from the mainland to restore control. ${ }^{70}$ When Elliot questioned the Italian premier Ricasoli on the matter, he found that the official line in the Italian capital was to deny that the revolt was in any way political. Even in his instructions to General Cadorna, who led the Italian military campaign and who was himself convinced of the political motives behind the revolt, Ricasoli insisted that there were 'no political crimes in the Palermo events'. ${ }^{71}$ By contrast Goodwin, who saw the events for himself after being awoken one morning by the sound of gunfire, explained that the perpetrators included clerical and reactionary insurgents bearing images of saints as well as radicals who hoisted a large red flag in the city centre. After hearing radical and reactionary cries alongside one another

${ }^{66}$ See Colnaghi's enclosure in Paget to Clarendon, 22 Feb. I87o, TNA, FO45/r6I.

${ }^{67}$ Hudson to Russell, 30 Mar. I86I, TNA, FO 45/5.

${ }^{68}$ Elliot to Russell, I8 Mar. I864, TNA, FO 45/56.

${ }^{69}$ Bonham to Paget, 2 Feb. I869, copy included in Paget to Clarendon, 4 Feb. I869, TNA, FO 45/139.

${ }_{70}$ Lucy Riall, Sicily and the Unification of Italy: liberal policy and local power, I859-I866 (Oxford, I998), pp. $198-9$.

${ }^{71}$ Ibid., pp. 204-5. 
Goodwin concluded that the rising was indicative of the general Sicilian hostility to Italian rule. ${ }^{72}$ Elliot understood this as the natural result of the 'injustice' and 'spoliation' forced on the island by the Italian government's policy of 'Piedmontization' irrespective of the wishes of the people, and shrewdly observed that the islanders remained Sicilian before they were Italian. ${ }^{73}$ In this way Goodwin demonstrated his value to a Foreign Office which Lionel Sackville West, the secretary of the British legation to Italy, had recommended to dispense with his services on account of his commercial reports being 'virtually useless' ${ }^{74}$

Throughout the nineteenth century the quality of British consular personnel varied enormously. In 1825 the service was taken out of private hands and placed under government control in an effort to improve its utility. Despite frequent calls to professionalize it, including the recommendations of three parliamentary select committees, ${ }^{75}$ the reluctance of successive governments to commit to the expense of reform ensured that it remained only a semi-professional organization. In comparison with its diplomatic counterpart the consular service was hampered by poor prestige; Disraeli described it as a 'refuge for the destitute' and the leastpromising offspring of any notable family. ${ }^{76}$ A strict fiscal regime imposed by the treasury ensured that consular salaries were relatively low and that most vice-consuls received no salary at all. Consequently many recruits were native residents or expatriates with their own private income, who took on the work in return for whatever prestige or other kinds of financial gain it might yield. This led to frequent debates over whether or not the government should insist upon appointing officials who were of British nationality, ${ }^{\mathbf{7 7}}$ and whether or not its personnel should be permitted to engage in trade. ${ }^{78}$ The service also lacked a rigid hierarchy, and the fact that appointments were made ultimately at the discretion of the foreign secretary ensured that there was no guarantee either seniority or merit would be rewarded. ${ }^{79}$

Under these circumstances it is not surprising that the consular service struggled to attract suitable personnel, and that some appointments were wholly inappropriate. In I858 a post was created at La Spezia for Charles Lever, whose qualifications included a fashionable literary reputation and connections in the Conservative party; revealingly, Lever had asked to be appointed to Naples but was considered unsuitable for such an important post. ${ }^{80}$ He repaid his employers'

72 John Goodwin, 'Seven days of disturbance in Palermo', 9 Oct. I866, copy in Elliot to Stanley, I3 Oct. I866, TNA, FO 45/9o. $\quad{ }^{73}$ Elliot to Stanley, 22 Sept. I866, TNA, FO 45/89.

74 Lionel Sackville West, 'Remarks upon the consular service in Italy', in Hudson to Russell, I July I862, TNA, FO 45/24.

75 See Report of the select committee on consular establishment, Parliamentary Papers (hereafter PP) I835 VI; Report from the select committee on consular service and appointments, PP I857-8 VIII; Report of the select committee on the diplomatic and consular services, PP I872 VII.

76 Platt, 'The role of the consular service in overseas trade, I825-I9I4', p. 497.

77 For each side of the argument see Jackson, Reflections on the commerce of the Mediterranean, p. 4I, and Tuson, The British consul's manual, pp. 6-7. $\quad{ }_{78}$ Platt, The Cinderella service, pp. I5, 3I, 37.

${ }^{79}$ Ibid., pp. 49, 5I. $\quad{ }^{80}$ Noel Blakiston, Inglesi e Italiani nel Risorgimento (Catania, I973), p. 43. 
generosity by spending lengthy periods absent without leave, or sailing around the bay in the hope of irritating his French counterpart. ${ }^{81} \mathrm{In}$ the still-independent city of Rome Joseph Severn offended the papal authorities by decorating his consulate with the Italian tricolore; the resident British diplomat Odo Russell described the ageing artist as 'utterly unfit and unqualified for his post' ${ }^{82}$ In Livorno the competent Consul Macbean's business as a merchant prevented him from attending his office before the afternoon and soured his relationship with the British community which he was appointed to serve. ${ }^{83}$ The fact that such men remained in office is perhaps indicative of the premium placed on their role as observers of Italian affairs rather than on their commercial responsibilities. In Palermo and Livorno Goodwin and Macbean each proved their worth in this respect; the post at La Spezia was not of sufficient political importance to justify removing Lever, while in Rome Severn's political responsibilities were minimized by the presence of Odo Russell. ${ }^{84}$

Of course, if events dictated that the British government should maintain a close watch on any particular location, the Foreign Office could ensure the appointment of an individual with the appropriate skills and experience. When unification necessitated the reorganization of the consular service in Italy, the ability of consuls to act as collectors of political intelligence took priority over their traditional commercial role. When a new consulate-general was opened at Milan in I860, the Foreign Office created a post which was rare in Europe; such prestigious and expensive offices were more frequently used elsewhere in the world in the place of diplomatic missions. A consul-general would be expected to communicate directly with the Foreign Office (as opposed to doing so through a diplomatic representative) on a more regular basis than an ordinary consul. During the i850s and I86os a number of consulates-general were used to collect information on political affairs in pre-unification Germany, and it has been suggested that the office in Milan was opened in order to monitor developments in Lombardy after its passage from Austrian to Piedmontese rule. ${ }^{85}$ This is supported by the fact that although there was seldom any occurrence of transferral of personnel between the diplomatic and consular professions, the new consul-general Loftus Otway was a former diplomat rather than a consul. ${ }^{86}$ This exceptional appointment suggests that in Milan the commercial experience of a consul was not required so much as the ability to comment on political affairs more associated with a diplomat. Furthermore, the office was closed again on

${ }^{81}$ Hudson to Russell, 4 Oct. I862, RP, TNA, PRO 30/22/69.

${ }^{82}$ Blakiston, ed., The Roman question, p. xix.

${ }^{83}$ Sackville West's 'Remarks upon the consular service in Italy', in Hudson to Russell, I July I862, TNA, FO $45 / 24$.

${ }^{84}$ For Russell's role, see Blakiston, ed., The Roman question; Urbach, Bismarck's favourite Englishman, pp. 34-9. $\quad{ }_{85}$ Platt, The Cinderella service, p. I8.

${ }_{86}$ Otway had held high diplomatic posts in Spain and Mexico; Foreign office list (London, Jan. I86r), p. II9. 
Otway's death after a mere eighteen months of operation. ${ }^{87}$ By that time Milan was quite peaceful, and the excitement in Italian affairs had shifted towards Naples, and southern resistance to northern rule. Similarly the costly British consulate-general in Venice was closed in I872, after the city had passed from Austrian to Italian rule and ceased to be a centre of international intrigue, but despite having lost none of its commercial importance or popularity with British visitors.

As the British consular presence was reduced in areas of relative tranquillity, it was increased where there was turmoil. The closure of the high-ranking office in Milan was followed promptly by the elevation of the existing consulate at Naples to the status of a consulate-general. Although this move has been explained as a reward for the long-serving Edward Bonham, ${ }^{88}$ such promotions were very unusual under the strict fiscal regime then prevailing at the Foreign Office. Moreover, it cannot be a coincidence that the decision was taken soon after the famous expedition of Garibaldi and the Thousand in I86o had effectively imposed upon Naples a fate similar to that which would be inflicted upon Turin by the September Convention after I864 - demotion from a state capital to a regional city. Prior to unification there had been widespread anticipation in northern Italy that the south was a land rich with resources, and considering the way in which Piedmont had prospered under the constitutional rule of Cavour during the $185 \mathrm{Os},{ }^{89}$ it was reasonable to assume that the extension of that government to southern Italy would make it prosperous. ${ }^{\mathbf{9 0}}$ It was only as the Piedmontese attempted to extend their administration through southern Italy and Sicily that this hope was destroyed by the discovery of the horrific reality of the south, ${ }^{91}$ a land and people which to them seemed more African than European. ${ }^{92}$ The poverty and corruption of Italy's most remote territories, their often mountainous terrain, their poor communications infrastructures, and their variety of incomprehensible dialects all complicated the task of assimilating them into the new Italian state. ${ }^{93}$ The Piedmontese quickly lost patience and sought to establish their authority over the south by increasingly brutal means, and a virtual civil war dragged on until i865. Both the rejection of northern rule by the southern population and the harsh repression to which the Italian authorities were forced to resort were profoundly embarrassing to the country's new liberal leaders, who could hardly be relied upon to share the details of either

\footnotetext{
${ }^{87}$ Hammond (for Russell) to Reynolds, II Oct. I86I, copy included in Reynolds to Hudson, I4 Oct. I86ı, TNA, FO I67/125. 88 Platt, The Cinderella service, p. 6I.

${ }^{89}$ See A. Scirocco, L'Italia del Risorgimento, I80o-I86o (Bologna, I990), pp. 315-66.

${ }^{90}$ Roger Absalom, Italy since I80o: a nation in the balance? (London and New York, NY, I995), p. 47.

${ }^{91}$ John Dickie, 'Stereotypes of the Italian south', in R. Lumley and J. Morris, eds., The new history of the Italian south: the Mezzogiorno revisited (Exeter, 1997), I22.

${ }^{92}$ Nelson Moe, The view from Vesuvius: Italian culture and the southern question (Berkeley, CA, 2002), pp. $162-8$.

${ }^{93}$ See L. J. Riall, 'Liberal policy and the control of public order in western Sicily, I860-1862', Historical Foumal, 35 (1992), pp. 345-68.
} 
with British representatives. As the senior British official in southern Italy following the closure of the diplomatic legation in Naples in 186o, Bonham bore the greatest responsibility for monitoring these affairs. As a consul-general he could be relied upon to preside over the hierarchy of consular officers in southern Italy and to communicate directly with the Foreign Office in London as well as with the British diplomatic mission in Turin.

The eagerness with which British leaders aimed to follow these events is further indicated by the fact that, in addition to Bonham's promotion, three diplomatic representatives were enlisted briefly as special observers in the south. Early in I86I the foreign secretary engaged the services of Peter Browne, a retired diplomat resident in Naples, to correspond privately with him on affairs in the former Bourbon capital. ${ }^{94}$ At around the same time Dudley Saurin, an attaché normally affiliated to the British legation in Turin, was sent to Naples to take charge of the archives of the erstwhile diplomatic office in the city. However, the real motive for the young attaché's sojourn might well have been quite different, as particular use was made of his presence to obtain information on an unpleasant incident in Abruzzo, a region which saw some of the worst disorder in Italy and which possessed not a single British consular office. When an alliance of rebels led by a notorious local brigand seized a small town near Foggia, it was presumably the reluctance of Italian officials to share accurate intelligence on the embarrassing episode which prompted Saurin to travel there in order to cover the event. Although the bersaglieri managed to defeat the rebels, Saurin found that the new state faced 'incalculable' difficulties in the region, owing to its 'hopeless demoralization', the corruption of its ruling elite and legal system, insufficient numbers of carabinieri, and the fact that its population did not 'care for the Italian cause ${ }^{95}$ Subsequently the foreign secretary despatched the young diplomat Laurence Oliphant upon an Italian tour which concentrated on such unruly and remote regions as the Abruzzo, Russell emphasizing his desire for 'accurate information' on their conditions and the state of public opinion. ${ }^{96}$ When Bonham described Italy's southern provinces as still being in an 'alarming state' in I866, by which time Browne, Saurin, and Oliphant had all departed, Elliot acknowledged that the consul-general was in the best position from which to judge. ${ }^{97}$

However, nowhere is there stronger evidence of the British government's determination to use its consular service in Italy for the purpose of gathering political intelligence than in the contrasting cases of Florence and Turin. When Tuscany was annexed to Piedmont in I859, it experienced a far more peaceful transition to Piedmontese rule than southern Italy after i86r. When the diplomatic corps departed from Florence the Foreign Office determined that no consular presence would be required in its place. For a short period Henry

\footnotetext{
94 For Browne's private letters presented as official despatches see RP, TNA, PRO 30/22/72.

95 Saurin to Hudson, I2 June I86I, in Papers respecting the affairs of southern Italy, PP I86I LXVII 375 , pp. 25-7. $\quad{ }_{96}$ Hudson to Russell, 20 May i862, TNA, FO $45 / 23$.

97 Elliot to Russell, c. 22 June I866, TNA, FO 45/87.
} 
Fenton, an attaché affiliated to the former British legation, remained in order to report on its affairs and 'to be of service to English travellers and residents who may require assistance ${ }^{9}{ }^{98}$ The move might well be considered to have prioritized the task of observation rather than attending the needs of the many British residents and visitors to Florence; Fenton was removed as soon as the city was peacefully assimilated into the Italian state, ${ }^{99}$ regardless of the fact that its diminished political importance did not alter the size of its British community. As a result of the subsequent lack of British representation in Florence the foreign secretary received a petition of eighty signatures, forwarded by Hudson, who urged him to appoint an agent 'to protect British interests in that city'. ${ }^{100}$ The petitioners suggested that the Foreign Office was aware of the need for representation in Florence, having declared the consul at Livorno to be responsible for their needs. But despite the fact that Livorno lay some distance away, and regardless of Consul Macbean's recommendations that another consulate should be opened to take pressure off his own post, ${ }^{101}$ the foreign secretary insisted that there was 'no sufficient reason on public grounds for the appointment of a British agent at Florence'. ${ }^{102}$ Hudson wrote a further request for the extension of consular representation to the city, predicting that it would increase in importance owing to its location on the new Italian rail network. ${ }^{103}$ Only in 1863 did Russell finally acquiesce by appointing Charles Proby as an unsalaried viceconsul in Florence. ${ }^{104}$ Clearly the government was not interested in appointing a representative for the mundane purpose of attending to the needs of the large expatriate community and high numbers of British visitors in the peaceful city.

When the same problem occurred again in Turin upon the transfer of the Italian government to Florence in I865, the British government's behaviour was strikingly different. With the whole of northern Italy rendered devoid of any form of British representation except for the consulate at Genoa and a number of small vice-consulates, the government recognized immediately that there was a need to establish a new consular office in either Turin or Milan. Although neither city attracted British visitors to their art and architecture in the same manner as other Italian cities, their location near the Alpine passes made them popular stopovers for travellers entering the peninsula. More importantly, they were two of the most important financial centres in Italy, ${ }^{105}$ and their significance in both respects seemed set to rise with the impending completion of the Mont Cenis railway,

\footnotetext{
98 Russell to Hudson, i7 Apr. I86o, TNA, FO ı67/ıг2.

99 Foreign Office list (Jan. I86I), p. 8I.

100 Petition dated I2 Feb. I86I, and enclosed in Hudson to Russell, I8 Feb. I86I, FO 45/4.

101 Macbean to Hudson, 20 Oct. I86o, and i6 Nov. I86o, TNA, FO I67/i ig.

102 Russell to Hudson, draft copy, 28 Feb. I86I, TNA, FO 45/I.

103 Hudson to Russell, i8 Oct. I86I, TNA, FO 45/9.

104 Proby was appointed on I May I863 and remained in office until the Italian government was moved to Florence in 1865 . Foreign Office list (Jan. I870), p. I50.

105 Gianni Toniolo, An economic history of liberal Italy, I850-I9I8 (London and New York, NY, I990),
} p. 58 . 
which would soon enable direct rail travel between Paris and Turin. ${ }^{106}$ However, when it came to choosing to locate the new office in either Turin or Milan, the selection was apparently determined by political considerations.

The decision to establish the new office was made on Elliot's recommendation. When the diplomat warned that Britons were likely to experience inconvenience 'by the want of any Consular Agent in the North of Italy', ${ }^{107}$ he stipulated that the new appointee ought to be an experienced professional consul, rather than a British resident or local merchant appointed to serve as an unsalaried vice-consul. The Foreign Office responded by creating a relatively well-paid consular post, ${ }^{108}$ and by appointing the professional Dominic Colnaghi who had several years' experience of service in Greece. What is most revealing is that despite acknowledging Milan's greater commercial importance and its higher volume of British travellers, Elliot insisted that the new consulate should be established in Turin, and that his opinion prevailed over that of the new foreign secretary Lord Clarendon. Elliot's choice shows that such considerations were of lesser importance than the desirability of maintaining an observer of political affairs in Piedmont. While the Unification of Italy was still widely perceived in Britain as the outcome of a popular movement, Elliot had been serving as a special envoy in Naples at the time of Garibaldi's arrival in I86o, and was well aware that many people had not welcomed it. After the September Convention had brought violence and tragedy to the streets of Turin in 1864, Elliot had arrived on the scene within minutes and appears to have been quite affected by the sight of the corpses. Thereafter he remained very much alive to the 'ill-humour' of the Turinese over the alleged subordination of their interests to those of the rest of Italy. ${ }^{109} \mathrm{He}$ also witnessed other public shows of disapprobation, such as the stoning of the royal carriage and disrespectful behaviour towards the king during his visit to the theatre on New Year's Day $1865 .{ }^{110}$ Upon his departure for Florence he noted the mutual regret of people and king at the departure of the government, and suggested that Turin had been hit hard by the loss of its status. ${ }^{111}$ The way in which the demotion of Naples had caused resentment and dragged the city and its hinterland into financial decline after I86o set a worrying precedent, and Elliot was driven to describe Turin as a 'dying capital'. ${ }^{112}$ For these reasons the diplomat insisted that even though Milan would be a more suitable location for a consulate under normal circumstances, it would be in the British interest to maintain Colnaghi in Turin as an informant on events and the state of public opinion in the city.

\footnotetext{
106 Pemble, The Mediterranean passion, pp. 26-7.

107 Elliot to Russell, 27 Apr. I865, TNA, FO $45 / 7$ I.

108 The salary was set at $£ 500$ per annum, with an expenses allowance of $£$ I5o. Foreign Office list (Jan. I870), p. I97.

109 H. G. Elliot, Some revolutions and other diplomatic experiences (London, I922), pp. I7I-9.

110 Elliot to Russell, by telegraph, 2 Jan. I862; Elliot to Russell, 6 Jan. I865, TNA, FO 45/7o.

111 Elliot to Russell, 9 Feb. I865, RP, TNA, PRO 30/22/70.

112 Elliot to Russell, 26 Apr. I865, RP, TNA, PRO 30/22/70.
} 
Within months of Colnaghi's arrival in Turin in I866, the foreign secretary sought to relocate his office to Milan. Again Elliot resisted Clarendon's preference for the Lombard city, stressing that there existed 'a considerable party' of discontented people in Turin which could 'at any time become a matter of extreme interest'. ${ }^{113}$ Elliot insisted that 'The Turinese are still very mad', and that it would be best to have 'someone who could keep us up to the state of feeling in Turin'. ${ }^{114}$ Clarendon's effort to transfer the office to Milan reflects his government's outward determination that the consular service was a commercial organization, while Elliot's insistence upon Turin is evidence of the determination of a diplomat to employ a consul as an accessory to aid him in his own role as a correspondent on political affairs. Ultimately Colnaghi's fully salaried consulate would remain in Turin for more than a decade, while Thomas Kelly was appointed as an unpaid, lower-ranking vice-consul to the more important commercial centre of Milan in $1867 .{ }^{115}$ The despatch briefing Colnaghi on his new role informed him that once at his post Elliot 'will furnish you with such Special Instructions as he may think necessary', ${ }^{116}$ further testifying to the link between diplomat and consul in the procurement of intelligence on Italian affairs.

Therefore British foreign secretaries and diplomats appear to have regarded the gathering of intelligence as the most important aspect of the consular service's role in Italy during the decade following its unification. If the creation of consulates-general at Milan and Naples during the early i86os suggests that the service was malleable towards this end, then the rejection of requests for an office in Florence and the subsequent creation of one in Turin rather than Milan provide confirmation. These actions might even be interpreted as part of a wellestablished interventionist streak in the British relationship with Italy. The country formed part of a strategic lifeline between Britain and its most important imperial possessions, ${ }^{117}$ and British governments had long sought to protect it from French ambitions. The British had sought to influence Italian affairs during the crises of $1847^{-} 9$ and $1859^{-60}$, sending special envoys to Italy's reactionary predecessor states in the hope of encouraging reforms, ${ }^{118}$ and providing unsolicited advice to constitutional governments in Piedmont. ${ }^{119}$ After Italian unification this trend continued, as Liberal foreign secretaries urged the leaders of the fledgling state to concentrate on providing good domestic government rather than pursuing international objectives. ${ }^{120}$ While Palmerston and Russell

\footnotetext{
${ }^{113}$ Elliot to Clarendon, 2I Feb. I866, TNA, FO 45/85.

114 Elliot to Murray, 2I Feb. I866, TNA, FO 45/85. ${ }^{115}$ Foreign Office list (Jan. I87o), p. I18.

116 Russell to Colnaghi, draft copy, 3I Aug. I865, TNA, FO 45/76.

${ }^{117}$ Ernle Bradford, Mediterranean: portrait of a sea (London, 2000), pp. $5^{\mathrm{IO}-\mathrm{I} 3}$.

118 See Justus B. Mugaju, 'Anglo-Italian relations, I846-I849: a study of British policy and attitudes towards Italy during the revolutionary years' (Ph.D. thesis, Bristol, 1976); Evelyn Ashley, The life and correspondence of Henry Fohn Temple, Viscount Palmerston, II (London, I879), p. 425; Elliot, Some revolutions, pp. $4^{-5}$.

119 Ronald Marshall, Massimo D'Azeglio: an artist in politics, I798-I866 (London, I966), p. I99.

120 Among many examples, see Russell to Hudson, 21 Jan. I86I, TNA, FO I67/I22 and Clarendon to Elliot, I2 Mar. I866, in Blakiston, ed., Il problema veneto, pp. 784-5.
} 
dominated foreign policy during the I85os and early I86os, the British government was generally assertive and interventionist in European affairs, ${ }^{121}$ and their approval of the Unification of Italy in I86o showed how effective they could be in making Britain's influence felt on the Continent. But their humiliation by Bismarck during the Danish crisis of 1864 led to criticism of their interventionism, ${ }^{\mathbf{1 2 2}}$ and resulted in a cross-party consensus on the benefits of remaining aloof from European affairs. ${ }^{123}$ Subsequent Conservative and Liberal governments sought to abstain from continental entanglements, even if such an approach was not enthusiastically embraced by a country used to Palmerston's bullish style and conscious of its wealth and power. ${ }^{124}$ However, as British foreign policy moved officially towards isolationism from the mid-I86os, the way in which consuls were used suggests that the Foreign Office nonetheless remained very interested in Italian affairs. The reorganization of the consular service in Italy, with its emphasis on the gathering of intelligence rather than other functions, is more consistent with British interventionism than isolationism. Either way, British consular staff formed an effective and reliable service providing generally accurate information for both the Foreign Office and their diplomatic colleagues throughout the i86os. At no point do they appear to have either questioned their obligation - or shown any hesitation - to do so.

121 See Donald Southgate, 'The most English minister ...' The policies and politics of Palmerston (London and New York, NY, I966); M. E. Chamberlain, British foreign policy in the age of Palmerston (London, I984); John Charmley, 'Palmerston: "Artful Old Dodger" or "Babe of Grace"??', in T. G. Otte, ed., The makers of British foreign policy: from Pitt to Thatcher (Basingstoke, 2002).

122 Wilbur Devereux Jones, Lord Derby and Victorian conservatism (Oxford, I956), pp. 278-9.

${ }^{123}$ Muriel E. Chamberlain, 'Pax Britannica'? British foreign policy, I789-19I4 (London and New York, NY, I988), pp. I23-7; Kenneth Bourne, The foreign policy of Victorian England (Oxford, I970), pp. 8I-I23; K. Theodore Hoppen, The mid-Victorian generation, I846-I886 (Oxford, I998), pp. 22I-36.

${ }^{124}$ Paul Kennedy, The rise and fall of British naval mastery (London, 200I), p. I8I; Charmley, 'Palmerston', pp. 92-4. 